\title{
SOIL FERTILITY, FINANCIAL SUPPORT, AND SUSTAINABLE COMPETITIVENESS: EVIDENCE FROM UKRAINE
}

Purpose. The purpose of this paper was to highlight the results of the study of the influence of the soil fertility and financial support on the formation of sustainable competitiveness of Ukrainian agricultural enterprises.

Methodology / approach. To achieve the purpose, we used such methods: correlation analysis (to identify and assess the close relationship between the ecological-agrochemical assessment of soils, financial support per hectare, and the sustainable competitiveness); econometric modeling (to develop a mathematical model of the dependence of the subindex of competitiveness by the yield on the ecological-agrochemical assessment of soils and the financial support per hectare); economic-statistical and monographic (for the assessment and analysis of the influence of the ecological-agrochemical assessment of soils and financial support per hectare on the formation of sustainable competitiveness); abstract-and-logical (for generalization and analysis of the research results); graphical (for the visual representation of the revealed dependencies). The study was performed on a selected sample of agricultural enterprises of districts of Kharkiv, Volyn and Chernihiv region, which represent all the soil-climatic zones of Ukraine. The time range of this research covers the years 2010-2016. The database of the 189 observations in Kharkiv region, 93 in Volyn region and 88 - in Chernihiv region was as the empirical basis.

Results. This paper presents empirical evidence for the impact of the soil fertility and financial support on the formation of sustainable competitiveness of enterprises. The obtained results prove the hypothesis of a positive relationship between the ecological-agrochemical assessment of soils, financial support per hectare, and the sustainable competitiveness of subjects, however, the level of impact of soil fertility differs significantly in different soil-climatic conditions. It is shown that soil fertility and financial support can sometimes act as substitutes, for example, in a zone of insufficient moisture or low soil fertility. Increasing the financial support for agricultural production per hectare may be a strategy to increase productivity when soils are less fertile.

Originality / scientific novelty. For the first time, one-and two-factor linear and quadratic econometric models were developed, which made it possible to carry out quantitative assessment of the impact of the ecological-agrochemical assessment of soils and the financial support per hectare on the formation of the subindex of competitiveness by the yield in various soil-climatic zones of Ukraine. The provision on the formation of the subindex of competitiveness by the yield under the conditions of the economic law of diminishing returns, was further developed.

Practical value / implications. The main results of the study can be used for (i) estimation and forecasting of the level of competitiveness depending on the ecological-agrochemical assessment of soils and the financial support per hectare; (ii) determining the effect of measures to improve the soil fertility on the competitiveness; (iii) determining the impact of soil degradation on competitiveness of agribusiness entities; (iv) identification of reserves to improve competitiveness. 


\section{Agricultural and Resource Economics}

www.are-journal.com

Key words: ecological-agrochemical assessment of soils, operating expenses, sustainable competitiveness, agricultural enterprises, Ukraine.

Introduction and review of literature. Soil fertility is one of the keys to future global food security. Scientists believe that «In addition to providing humanity with $98.8 \%$ of its food, soils provide a broad range of other services, from carbon storage and greenhouse gas regulation, to flood mitigation and providing support for our cities» [1]. But «... the current intensification of agricultural practices is already resulting in the unsustainable degradation of soils» [1]. Improved soil quality is required to sustainably achieve global food security [2]. Recently, numerous studies were devoted to the problem of assessing soil quality in different countries (Baliuk et al. [3]; Bartolomei et al. [4]; Colantoni et al. [5]; Huera-Lucero et al. [6]; Salvati et al. [7]; Vashisht et al. [8]) and innovative measures to improve (i) soil quality under different land use systems and (ii) food security under conservation agriculture (Abdul Rahman et al. [9]; Fantappiè et al. [10]; Mgolozeli et al. [11]; Pan et al. [2]). The results of studies indicate that «although the recycling of organic materials to fields is considered a key practice for improving soil quality, the effects of this procedure was found to reduce farm profitability due to increases in material costs and labour» [2]. However, the analysis reveals that the yield capacity of maize and wheat on average is higher under a larger content of organic carbon in the soil [12].

Foreign scientists pay much attention to the issues of knowledge of local farmers about soil quality, practice of sustainable management of fertility and indexes of land degradation (Ansong Omari et al. [13]; de Souza Mello Bicalho and dos Guimarães Peixoto [14]; Kuria et al. [15]). Results of the theoretical analysis of empiric researches on the impact of ecological standards on competitiveness of enterprises demonstrate they can influence both negatively and positively, in particular stimulating introduction of ecological innovations [16]. Australian scientists report a strong positive association between environmental performance and financial performance during the pre-financial crisis period (2001-2007) and no relationship between environmental performance and financial performance during the financial crisis (2008-2010) [17]. Foreign researchers emphasize the relations of agricultural landscapes, ecosystem services and regional competitiveness being extended behind the agriculture [18], as well as the relationship between soil fertility, biological diversity of agricultural crops and income of the farmers in Italy [19]. The study of competitiveness of the agricultural enterprises in Slovak Republic highlights that better results are found in the group of enterprises, which run their activities under better soil and natural conditions [20]. In two regions (i.e. Brest and Minsk) and in Belarus generally, the correlation dependence between the yield capacity and the rating of soil fertility is very strong, whereas in the other regions it is at the average level [21]. The works by A. Issanchou and coauthors provide the most detailed study of the economic issue of soil quality management in terms of maintenance of competitiveness and sustainable agriculture, as well as its impact on French farms' profitability [22-25]. 


\section{Agricultural and Resource Economics \\ www.are-journal.com}

In Ukraine, works by the scientists deal with the problems of (i) balancing of the economic conditions of farming on the land of different quality [26]; (ii) assessing the impact of land quality on the yield capacity of winter wheat grain [27]; (iii) correlation analysis of dependence between the land evaluation in points and yield capacity of agricultural crops [28]. However, in Ukraine there are no studies on the impact of soil fertility, soil and land quality on the sustainable competitiveness of agricultural enterprises. Based on the analysis of articles on sustainable competitiveness published in journals indexed by Scopus during 1981 and 2019 (Fig. 1), we identified (i) a trend towards a rapid increase (especially since 2010) in the number of publications in the world (leaders - China, USA and United Kingdom), and (ii) research gaps in Ukrainian literature (only 59 documents were published during the analyzed period), that have not yet been addressed.

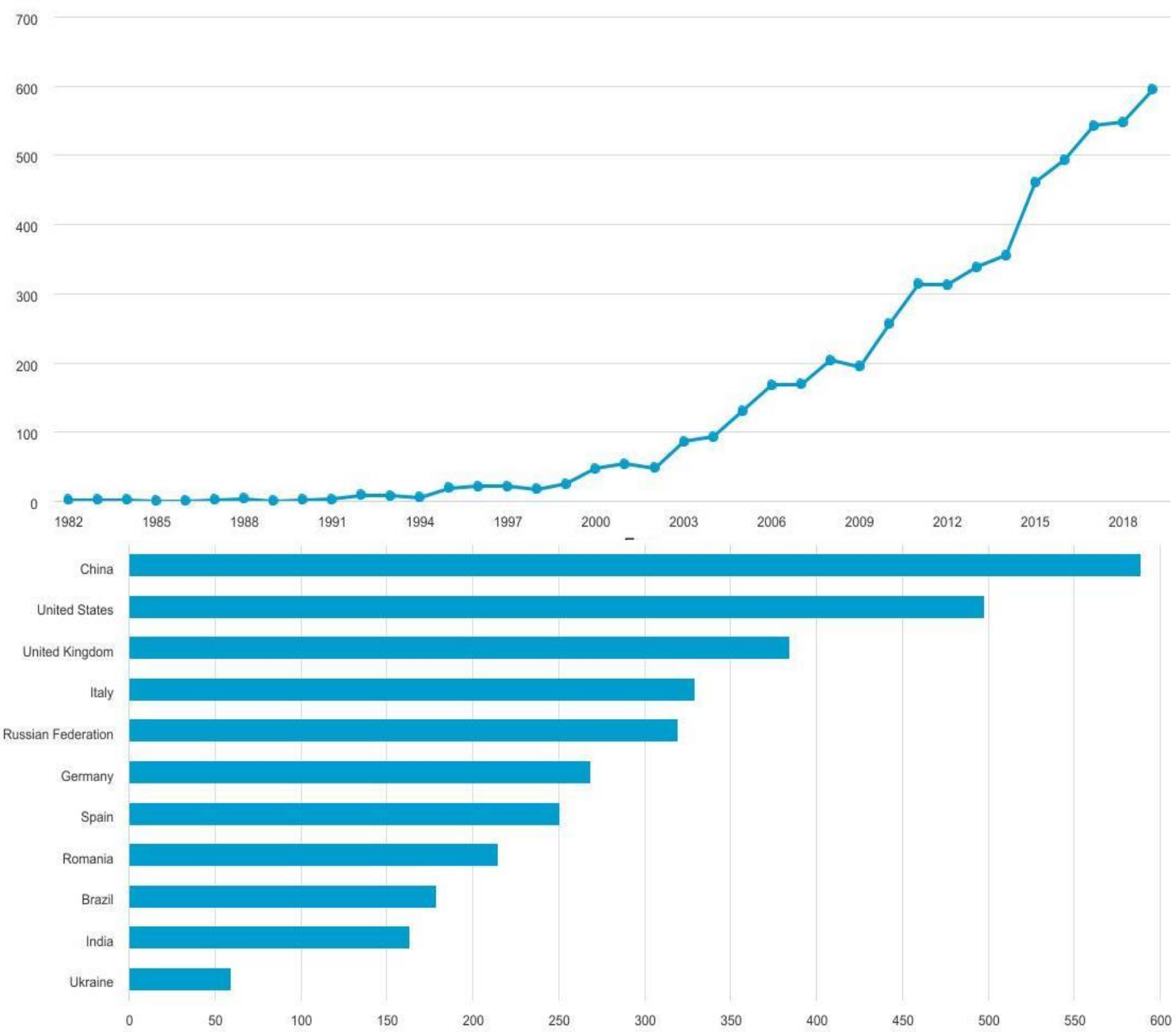

Fig. 1. Number of documents on sustainable competitiveness published in journals indexed by Scopus in dynamics and in the TOP-10 countries and Ukraine

Source: built by the author according to the search and analysis of the documents in Scopus (https://www.scopus.com). 


\section{Agricultural and Resource Economics}

www.are-journal.com

In our previous studies, taking into account the concept of sustainable development, the concept of «sustainable competitiveness of agricultural enterprises» was introduced into scientific circulation, a methodology for assessing the sustainable competitiveness of agricultural enterprises was proposed and tested [29]; the holistic conception of the formation of sustainable competitiveness of agricultural enterprises based on sustainable soil management was developed [30]; assessment and cluster analysis of the sustainable competitiveness of agricultural enterprises carried out [31]; the impact of land quality and balance of soil organic carbon on the formation of sustainable competitiveness of agricultural enterprises was evaluated [32;33].

On the other hand, many papers have highlighted the need for improve financial support of Ukrainian agricultural enterprises [34-39]. However, the problem of assessing the simultaneous effect of soil fertility and financial support on the competitiveness of agricultural enterprises in Ukraine is still poorly studied. So, the above indicates the relevance, scientific novelty and practical value of the problem of assessing the influence of the soil fertility and financial support on the formation of sustainable competitiveness of agricultural enterprises, therefore, the proposed article is a logical continuation of the author's systematic scientific research on this topic.

The purpose of the article. The purpose of this paper was to highlight the results of the study of the influence of the soil fertility and financial support on the formation of sustainable competitiveness of Ukrainian agricultural enterprises.

Methodology. The hypothesis of the research is based on the assumptions that: (i) there is positive relations between the ecological-agrochemical assessment of soils and subindexes of sustainable competitiveness of agricultural enterprises; (ii) the dependence between the level of financial support (investments of costs (expenditures) per hectare) and the subindexes of sustainable competitiveness of agricultural enterprises is positive nature.

Considering zonal features of formation of sustainable competitiveness of agricultural enterprises [40], our research was carried out on the example of agricultural enterprises of districts of Kharkiv, Volyn and Chernihiv region, which represent all the soil-climatic zones of Ukraine (Fig. 2). The study area, Kharkiv, Volyn and Chernihiv region, is one of the typical agroindustrial regions in Ukraine.

To achieve the purpose, we used such methods: correlation analysis (to identify and assess the close relationship between the ecological-agrochemical assessment of soils, financial support per hectare, and the sustainable competitiveness); econometric modeling (to develop a mathematical model of the dependence of the subindex of competitiveness by the yield on the ecological-agrochemical assessment of soils and the financial support per hectare); economic-statistical and monographic (for the assessment and analysis of the influence of the ecological-agrochemical assessment of soils and financial support per hectare on the formation of sustainable competitiveness); abstract-and-logical (for theoretical generalization and analysis of the research results); graphical (for the visual representation of the revealed dependencies). This study was performed on a selected sample of agricultural enterprises of districts of Kharkiv, Volyn and Chernihiv region. The time range of 


\section{Agricultural and Resource Economics}

www.are-journal.com

this research covers the years 2010-2016. To receive the results, the statistical software package STATISTICA is used.

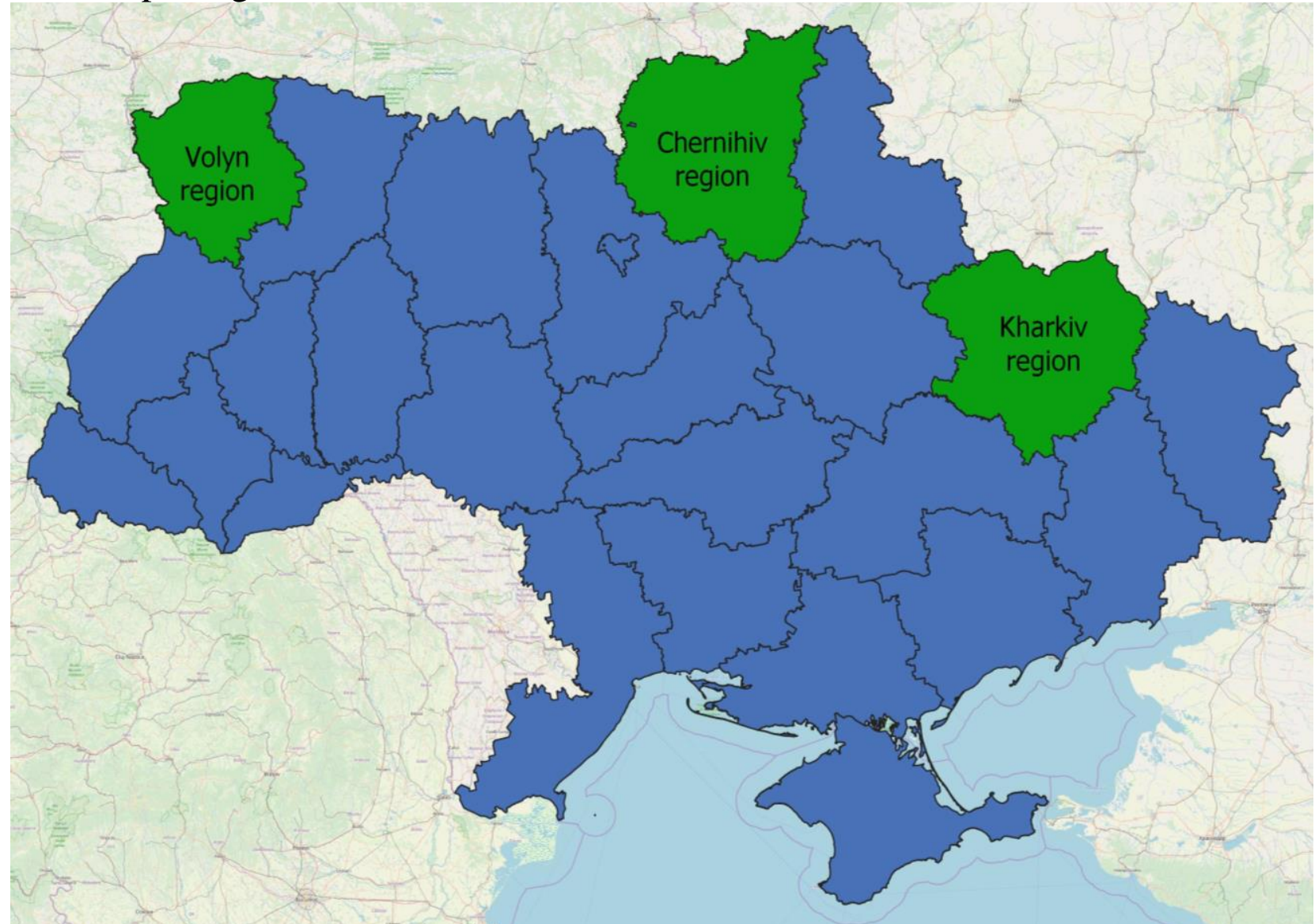

Fig. 2. Map of Ukraine showing the boundary of the study area

Source: compiled by the author.

This study is based on statistical and empirical monitoring data for the years 2010-2016 at the level of administrative districts of Kharkiv, Volyn and Chernihiv regions of Ukraine. The amount of financial support per hectare and subindexes of sustainable competitiveness calculated according to the information of the regional affiliates of the State Statistics Service of Ukraine (form No. 50-s.g.). The database of the average ecological-agrochemical assessment of soils of arable land in the administrative districts of the analyzed regions of Ukraine, was used as the empirical basis on soil fertility. This data was obtained from the State Institution «Soils Protection Institute of Ukraine» [41] and its regional affiliates. The database of the 189 observations in Kharkiv region, 93 - in Volyn region and 88 - in Chernihiv region was as the empirical basis.

Results and discussion. At the first stage, the research assessed relations between the average ecological-agrochemical assessment of soils of arable land and subindexes of sustainable competitiveness of agricultural enterprises (Tables 1-3). In the system of correlation relationships between the ecological-agrochemical assessment of soils and the main subindexes of sustainable competitiveness of agricultural enterprises in Kharkiv region, it is the most clearly observed at the low and moderate level with the subindexes of competitiveness by the selling price per 


\section{Agricultural and Resource Economics}

www.are-journal.com

1 centner of maize grain and sunflower. In other cases, this relationship was absent or statistically unreliable.

Table 1

Linear coefficients of pair correlation between ecological-agrochemical assessment of soils and main subindexes of sustainable competitiveness of agricultural enterprises of the districts of Kharkiv region

\begin{tabular}{|c|c|c|c|c|c|c|c|c|}
\hline \multirow{2}{*}{ Indicators } & \multicolumn{7}{|c|}{ Years } & \multirow{2}{*}{$\begin{array}{l}\text { On average } \\
\text { for the years } \\
2010-2016\end{array}$} \\
\hline & 2010 & 2011 & 2012 & 2013 & 2014 & 2015 & 2016 & \\
\hline \multicolumn{9}{|c|}{ Competitiveness subindex by the yield } \\
\hline Grains, total & 0.043 & -0.069 & -0.229 & -0.008 & -0.301 & 0.005 & -0.181 & -0.121 \\
\hline Winter wheat grain & 0.144 & -0.292 & -0.224 & -0.017 & -0.384 & 0.073 & -0.072 & -0.104 \\
\hline Maize for grain & 0.271 & 0.141 & -0.174 & -0.065 & -0.103 & -0.102 & -0.127 & -0.026 \\
\hline Sunflower & 0.186 & 0.083 & 0.012 & -0.178 & -0.333 & -0.067 & 0.106 & -0.046 \\
\hline \multicolumn{9}{|c|}{ Competitiveness subindex by the production cost per 1 centner } \\
\hline Grain: & -0.099 & -0.011 & 0.107 & -0.011 & 0.090 & 0.0002 & 0.290 & -0.055 \\
\hline Winter wheat grain & -0.115 & 0.066 & 0.100 & -0.134 & 0.195 & -0.114 & 0.133 & 0.045 \\
\hline Maize for grain & -0.273 & -0.067 & 0.131 & -0.070 & -0.059 & 0.287 & 0.082 & -0.009 \\
\hline Sunflower & 0.231 & -0.055 & 0.350 & 0.011 & 0.176 & 0.074 & -0.054 & -0.154 \\
\hline \multicolumn{9}{|c|}{ Competitiveness subindex by the selling price per 1 centner } \\
\hline Grains, total & 0.434 & -0.183 & 0.017 & -0.207 & 0.085 & 0.005 & -0.049 & 0.157 \\
\hline Winter wheat grain & -0.128 & -0.261 & 0.015 & -0.109 & 0.054 & 0.108 & -0.071 & -0.076 \\
\hline Maize for grain & 0.468 & -0.058 & 0.074 & -0.124 & 0.062 & -0.187 & -0.093 & 0.202 \\
\hline Sunflower & 0.509 & -0.001 & 0.069 & 0.048 & 0.019 & 0.322 & 0.204 & 0.521 \\
\hline \multicolumn{9}{|c|}{ Competitiveness subindex by the covering of production expenses with cash revenue } \\
\hline Grains, total & 0.338 & -0.026 & -0.089 & -0.046 & 0.031 & 0.018 & -0.324 & 0.051 \\
\hline Winter wheat gra & 0.098 & -0.119 & -0.039 & 0.045 & -0.104 & 0.143 & -0.200 & 0.021 \\
\hline Maize for grain & 0.509 & 0.028 & -0.140 & -0.006 & 0.147 & -0.317 & -0.100 & 0.087 \\
\hline & & 0.056 & -0.359 & 0.001 & -0.091 & 4 & 0.024 & \\
\hline
\end{tabular}

Source: author's calculations based on data of the State Institution «Soils Protection Institute of Ukraine» and data of the form No. 50-s.g.

By contrast with Kharkiv region, in Volyn region, on the basis of the average indexes in the studied period we identified availability of mainly a high direct correlation relation between the ecological-agrochemical assessment of soils and the main subindexes of competitiveness by the yield of grains in total $(r=0.799$ average for seven years) and winter wheat grain particularly ( $r=0.802$ average for seven years), and the average direct correlation with the competitiveness by the yield of maize for grain ( $r=0.550$ average for seven years). In the variant of potato, the correlation relation was low for the seven-year period. The research identifies a moderate direct correlation relation between the ecological-agrochemical assessment of soils and the subindexes of competitiveness by the production cost per 1 centner of grains $(r=0.478)$ and potato $(r=0.402)$ for the seven-year period. The ecologicalagrochemical assessment of soils is characterized by a direct correlation relation with the subindexes of competitiveness by the covering of production expenses with cash revenue for grains at the level of average strength of relationship $(r=0.540)$, and 


\section{Agricultural and Resource Economics}

www.are-journal.com

moderate strength of relationship for grain of winter wheat $(r=0.457)$, grain of maize $(r=0.367)$ and potato $(r=0.482)$ for the seven-year period.

Table 2

Linear coefficients of pair correlation between ecological-agrochemical assessment of soils and main subindexes of sustainable competitiveness of agricultural enterprises of the districts of Volyn region

\begin{tabular}{|c|c|c|c|c|c|c|c|c|}
\hline \multirow{2}{*}{ Indicators } & \multicolumn{7}{|c|}{ Years } & \multirow{2}{*}{$\begin{array}{c}\text { On average } \\
\text { for the years } \\
2010-2016\end{array}$} \\
\hline & 2010 & 2011 & 2012 & 2013 & 2014 & 2015 & 2016 & \\
\hline \multicolumn{9}{|c|}{ Competitiveness subindex by the yield } \\
\hline Grains, total & 0.856 & 0.785 & 0.781 & 0.762 & 0.722 & 0.786 & 0.685 & 0.799 \\
\hline Winter wheat grain & 0.863 & 0.861 & 0.834 & 0.763 & 0.738 & 0.755 & 0.612 & 0.802 \\
\hline Maize for grain & 0.759 & 0.510 & 0.683 & 0.742 & 0.706 & 0.597 & 0.408 & 0.550 \\
\hline Potato & -0.019 & 0.031 & 0.428 & 0.468 & 0.687 & 0.291 & 0.116 & 0.246 \\
\hline \multicolumn{9}{|c|}{ Competitiveness subindex by the production cost per 1 centner } \\
\hline Grains, total & 0.546 & 0.445 & 0.502 & 0.478 & 0.437 & 0.134 & 0.087 & 0.478 \\
\hline Winter wheat grain & 0.646 & 0.370 & 0.451 & 0.482 & 0.385 & 0.218 & -0.383 & -0.244 \\
\hline Maize for grain & 0.159 & 0.038 & 0.179 & 0.270 & 0.240 & 0.253 & 0.179 & 0.287 \\
\hline Potato & -0.009 & 0.112 & 0.030 & 0.742 & 0.650 & 0.093 & 0.241 & 0.402 \\
\hline \multicolumn{9}{|c|}{ Competitiveness subindex by the selling price per 1 centner } \\
\hline Grains, total & 0.482 & -0.185 & 0.167 & -0.052 & 0.112 & 0.572 & 0.549 & 0.484 \\
\hline Winter wheat & 0.120 & 0.020 & 0.228 & 0.151 & 0.393 & 0.461 & 0.335 & 0.343 \\
\hline Maize for grain & -0.581 & -0.150 & 0.067 & 0.109 & -0.181 & 0.392 & -0.161 & -0.184 \\
\hline Potato & 0.082 & -0.029 & -0.042 & -0.017 & -0.180 & 0.100 & -0.338 & -0.186 \\
\hline \multicolumn{9}{|c|}{ Competitiveness subindex by the covering of production expenses with cash revenue } \\
\hline Grains, total & 0.595 & 0.412 & 0.488 & 0.396 & 0.424 & 0.444 & 0.345 & 0.540 \\
\hline Winter wheat gra & 0.543 & 0.399 & 0.498 & 0.520 & 0.517 & 0.418 & 0.313 & 0.457 \\
\hline Maize for grain & -0.150 & 0.243 & 0.255 & 0.538 & 0.176 & 0.373 & 0.165 & 0.367 \\
\hline Potato & 0.036 & 0.506 & 0.484 & 0.695 & 0.298 & 0.182 & 0.082 & 0.482 \\
\hline
\end{tabular}

Source: author's calculations based on data of the State Institution «Soils Protection Institute of Ukraine» and data of the form No. 50-s.g.

Similar correlation relations are found in Chernihiv region. Thus, in the system of relationship between the ecological-agrochemical assessment of soil and analyzed subindexes, the relation with competitiveness by the yield of grains $(r=0.680$ average for seven years) and sunflower $(r=0.769)$ was the highest by the degree strength and resistance in time. Although there was no clear tendency in the dynamics of changes of the mentioned coefficients of pair correlation, the general trend can be characterized as positive, at least because its value in the sample period was higher than in the basic one. The subindex of competitiveness by the yield of potato was characterized by an inverse correlation relation with the ecological-agrochemical assessment of soil. It is probably related with other factors of its formation, particularly such as weather-climatic conditions in the year and financial support of production. The subindexes of competitiveness by the production costs of $1 \mathrm{c}$ of grains in total, including winter wheat, directly correlated with the ecologicalagrochemical assessment of soils at the level of a moderate strength of the relation. In 


\section{Agricultural and Resource Economics}

www.are-journal.com

other cases, that relation was weak and/or inverse, or totally absent. The coefficients of pair correlation between the subindexes of competitiveness by the sale price of $1 \mathrm{c}$ significantly fluctuated in the dynamics and, by the average figures for the seven-year period, confirmed a direct moderate relation on the example of maize grain $(r=0.350)$, and weak correlation concerning the grain of winter wheat $(r=0.158)$ and potato $(r=0.214)$. Increasing of the ecological-agrochemical assessment of soil positively and moderately correlated with the subindexes of competitiveness by the recovery of production costs by means of income of all kinds of products, but not for sunflower. Thus, an increase of the ecological-agrochemical assessment of soil secured a successful competition at the market of grains due to obtaining of larger amounts of products from 1 ha and leadership by the costs, whereas at the market of sunflower - due to a higher yield capacity, and at the market of potato - due to its better quality (a higher sale price) and better covering of production expenses with cash revenue.

Table 3

\section{Linear coefficients of pair correlation between ecological-agrochemical} assessment of soils and main subindexes of sustainable competitiveness of agricultural enterprises of the districts of Chernihiv region

\begin{tabular}{|l|c|c|c|c|c|c|c|c|}
\hline \multirow{2}{*}{ Indicators } & \multicolumn{7}{c|}{ Years } & $\begin{array}{c}\text { On average } \\
\text { for the years } \\
2010-2016\end{array}$ \\
\cline { 2 - 9 } & 2010 & 2011 & 2012 & 2013 & 2014 & 2015 & 2016 & 0.680 \\
\hline \multicolumn{7}{|c|}{ Competitiveness subindex by the yield } \\
\hline Grains, total & 0.517 & 0.671 & 0.679 & 0.610 & 0.658 & 0.685 & 0.699 & 0.769 \\
\hline Sunflower & 0.310 & 0.602 & 0.407 & 0.710 & 0.714 & 0.636 & 0.598 & -0.466 \\
\hline Potato & -0.130 & -0.561 & -0.472 & -0.130 & -0.484 & -0.309 & -0.373 & \\
\hline \multicolumn{7}{|c|}{ Competitiveness subindex by the production cost per 1 centner } \\
\hline Grains, total & 0.340 & 0.494 & 0.262 & -0.023 & $\mathrm{~N} / \mathrm{d}$ & $\mathrm{N} / \mathrm{d}$ & $\mathrm{N} / \mathrm{d}$ & 0.307 \\
\hline Winter wheat grain & 0.167 & 0.281 & 0.275 & 0.200 & $\mathrm{~N} / \mathrm{d}$ & $\mathrm{N} / \mathrm{d}$ & $\mathrm{N} / \mathrm{d}$ & 0.303 \\
\hline Maize for grain & 0.234 & 0.017 & -0.216 & -0.102 & $\mathrm{~N} / \mathrm{d}$ & $\mathrm{N} / \mathrm{d}$ & $\mathrm{N} / \mathrm{d}$ & -0.169 \\
\hline Sunflower & -0.271 & 0.421 & -0.198 & 0.060 & $\mathrm{~N} / \mathrm{d}$ & $\mathrm{N} / \mathrm{d}$ & $\mathrm{N} / \mathrm{d}$ & -0.171 \\
\hline Potato & 0.370 & -0.282 & -0.131 & 0.201 & $\mathrm{~N} / \mathrm{d}$ & $\mathrm{N} / \mathrm{d}$ & $\mathrm{N} / \mathrm{d}$ & 0.023 \\
\hline \multicolumn{7}{|c|}{ Competitiveness subindex by the selling price per 1 centner } \\
\hline Grains, total & 0.289 & -0.350 & 0.124 & 0.027 & 0.086 & -0.144 & -0.025 & 0.029 \\
\hline Winter wheat grain & 0.430 & 0.329 & 0.194 & -0.329 & -0.131 & 0.373 & 0.316 & 0.158 \\
\hline Maize for grain & 0.372 & 0.161 & 0.370 & 0.225 & 0.156 & -0.210 & 0.331 & 0.350 \\
\hline Sunflower & 0.358 & 0.254 & 0.121 & -0.262 & 0.097 & -0.017 & 0.388 & 0.032 \\
\hline Potato & 0.198 & 0.306 & 0.327 & -0.037 & $\mathrm{~N} / \mathrm{d}$ & $\mathrm{N} / \mathrm{d}$ & $\mathrm{N} / \mathrm{d}$ & 0.214 \\
\hline \multicolumn{7}{|c|}{ Competitiveness subindex by the covering of production expenses with cash revenue } \\
\hline Grains, total & 0.507 & 0.378 & 0.410 & 0.018 & $\mathrm{~N} / \mathrm{d}$ & $\mathrm{N} / \mathrm{d}$ & $\mathrm{N} / \mathrm{d}$ & 0.430 \\
\hline Winter wheat grain & 0.261 & 0.428 & 0.319 & 0.039 & $\mathrm{~N} / \mathrm{d}$ & $\mathrm{N} / \mathrm{d}$ & $\mathrm{N} / \mathrm{d}$ & 0.297 \\
\hline Maize for grain & 0.403 & 0.140 & 0.172 & 0.065 & $\mathrm{~N} / \mathrm{d}$ & $\mathrm{N} / \mathrm{d}$ & $\mathrm{N} / \mathrm{d}$ & 0.313 \\
\hline Sunflower & -0.191 & 0.604 & -0.186 & -0.140 & $\mathrm{~N} / \mathrm{d}$ & $\mathrm{N} / \mathrm{d}$ & $\mathrm{N} / \mathrm{d}$ & -0.272 \\
\hline Potato & 0.511 & 0.431 & 0.231 & 0.196 & $\mathrm{~N} / \mathrm{d}$ & $\mathrm{N} / \mathrm{d}$ & $\mathrm{N} / \mathrm{d}$ & 0.300 \\
\hline
\end{tabular}

Note. $\mathrm{N} / \mathrm{d}$ - no data.

Source: author's calculations based on data of the State Institution «Soils Protection Institute of Ukraine» and data of the form No. 50-s.g. 


\section{Agricultural and Resource Economics \\ www.are-journal.com}

The results of grouping of agricultural enterprises of the districts of Volyn region (Table 4) demonstrated that an increase of the ecological-agrochemical assessment of soil generally made a positive impact on their competitiveness at the market of grain of winter wheat, however, only the fourth group was competitive having 44 points of the average soil assessment.

Table 4

Impact of ecological-agrochemical assessment of soil on the sustainable competitiveness of agricultural enterprises of the districts of Volyn region on winter wheat grain market, 2010-2016

\begin{tabular}{|c|c|c|c|c|c|c|c|c|}
\hline \multirow{2}{*}{\multicolumn{2}{|c|}{$\begin{array}{l}\text { Groups of districts } \\
\text { by the ecological- } \\
\text { agrochemical } \\
\text { assessment of soils, } \\
\text { points }\end{array}$}} & \multirow[b]{2}{*}{$\begin{array}{c}\text { Number of } \\
\text { districts } \\
\text { in the group, } \\
\text { units }\end{array}$} & \multirow[b]{2}{*}{$\begin{array}{l}\text { Average of } \\
\text { ecological- } \\
\text { agroche- } \\
\text { mical } \\
\text { assessment } \\
\text { of soils, } \\
\text { points }\end{array}$} & \multicolumn{5}{|c|}{ Competitiveness subindex by: } \\
\hline & & & & $\frac{\frac{\partial}{d}}{\lambda}$ & 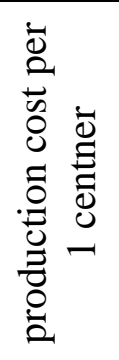 & 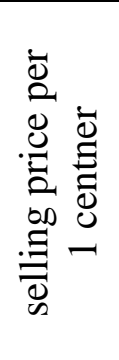 & 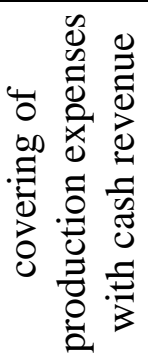 & 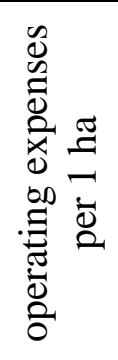 \\
\hline I & To 30 & 21 & 27 & 0.647 & 1.023 & 0.963 & 0.938 & 0.792 \\
\hline II & $31-35$ & 35 & 31 & 0.427 & 1.052 & 0.930 & 0.676 & 0.576 \\
\hline III & $36-40$ & 28 & 38 & 0.922 & 0.991 & 0.983 & 0.980 & 0.898 \\
\hline IV & Over 40 & 21 & 44 & 1.118 & 1.004 & 1.011 & 1.029 & 1.105 \\
\hline
\end{tabular}

Source: author's calculations based on the data of the form No. 50-s.g. and data of the State Institution «Soils Protection Institute of Ukraine».

It is determined that an increase of the ecological-agrochemical assessment of soil caused an increase of the subindexes of competitiveness by the yield, sale price and production expenses per 1 ha, although with some fluctuations. In particular, according to the yield factor, the second group was the absolute outsider that was caused not only by the ecological-agrochemical assessment of soil or by the size of production expenses, which were the smallest in that group. Nevertheless, the second group reached the best level by the production costs of $1 \mathrm{c}$. However, it was an outsider by the covering of production expenses with cash revenue.

Similar tendencies are identified in formation of competitiveness of agricultural enterprises on the soil with different ecological-agrochemical assessment in the Chernihiv region (Table 5). An increase of the mentioned assessment caused the increase of the subindex of competitiveness by the yield from 0.740 in the first group to 1.130 in the fifth group under the simultaneous growth of the subindex by the expenses costs per 1 ha from 0.854 to 1.087 respectively. The subindex of competitiveness by the cost of $1 \mathrm{c}$ demonstrated the overall tendency to increase, which was only violated by the enterprises of the fifth group that was also particular for the dynamics of the subindex of competitiveness by the covering of production expenses with cash revenue. Unlike the previous case, results of that grouping did not secure identification of the impact of fertility and quality of soil on formation of the sale prices of grain, because the corresponding subindex did not demonstrate clear tendencies in the dynamics. 
Table 5

Impact of ecological-agrochemical assessment of soil on the sustainable competitiveness of agricultural enterprises of the districts of Chernihiv region

on the grain market, 2010-2016

\begin{tabular}{|c|c|c|c|c|c|c|c|c|}
\hline \multirow{2}{*}{\multicolumn{2}{|c|}{$\begin{array}{l}\text { Groups of districts } \\
\text { by the ecological- } \\
\text { agrochemical } \\
\text { assessment of soils, } \\
\text { points }\end{array}$}} & \multirow[b]{2}{*}{$\begin{array}{c}\text { Number of } \\
\text { districts } \\
\text { in the group, } \\
\text { units }\end{array}$} & \multirow[b]{2}{*}{$\begin{array}{l}\text { Average of } \\
\text { ecological- } \\
\text { agroche- } \\
\text { mical } \\
\text { assessment } \\
\text { of soils, } \\
\text { points }\end{array}$} & \multicolumn{5}{|c|}{ Competitiveness subindex by: } \\
\hline & & & & $\frac{\overrightarrow{0}}{\frac{0}{\lambda}}$ & 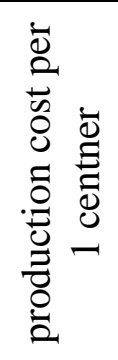 & 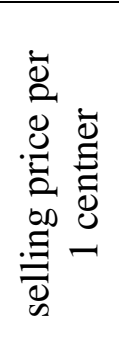 & 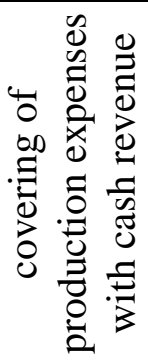 & 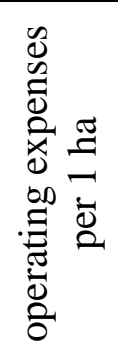 \\
\hline $\mathrm{I}$ & To 35 & 21 & 34 & 0.740 & 0.878 & 0.990 & 0.874 & 0.854 \\
\hline II & $36-40$ & 35 & 37 & 0.716 & 0.881 & 1.002 & 0.862 & 0.865 \\
\hline III & $41-45$ & 35 & 43 & 0.825 & 1.001 & 0.917 & 0.899 & 0.918 \\
\hline IV & $46-50$ & 28 & 49 & 1.089 & 1.033 & 0.957 & 1.005 & 1.072 \\
\hline $\mathrm{V}$ & Over 50 & 35 & 55 & 1.130 & 0.979 & 0.993 & 0.972 & 1.087 \\
\hline
\end{tabular}

Source: author's calculations based on the data of the form No. 50-s.g. and data of the State Institution «Soils Protection Institute of Ukraine».

The dependence of the subindex of competitiveness by the yield of grains on the ecological-agrochemical assessment of soil is approximated by the equation of a straight line (Fig. 3). Referring to it, an increase of the mentioned assessment by 1 point caused the increase of the mentioned subindex by 0.022 . The author identifies a notable direct correlation relation $(r=0.639)$, whereas variation of the dependent variable is by $40.8 \%$ dependent on the fluctuation of the factorial index.

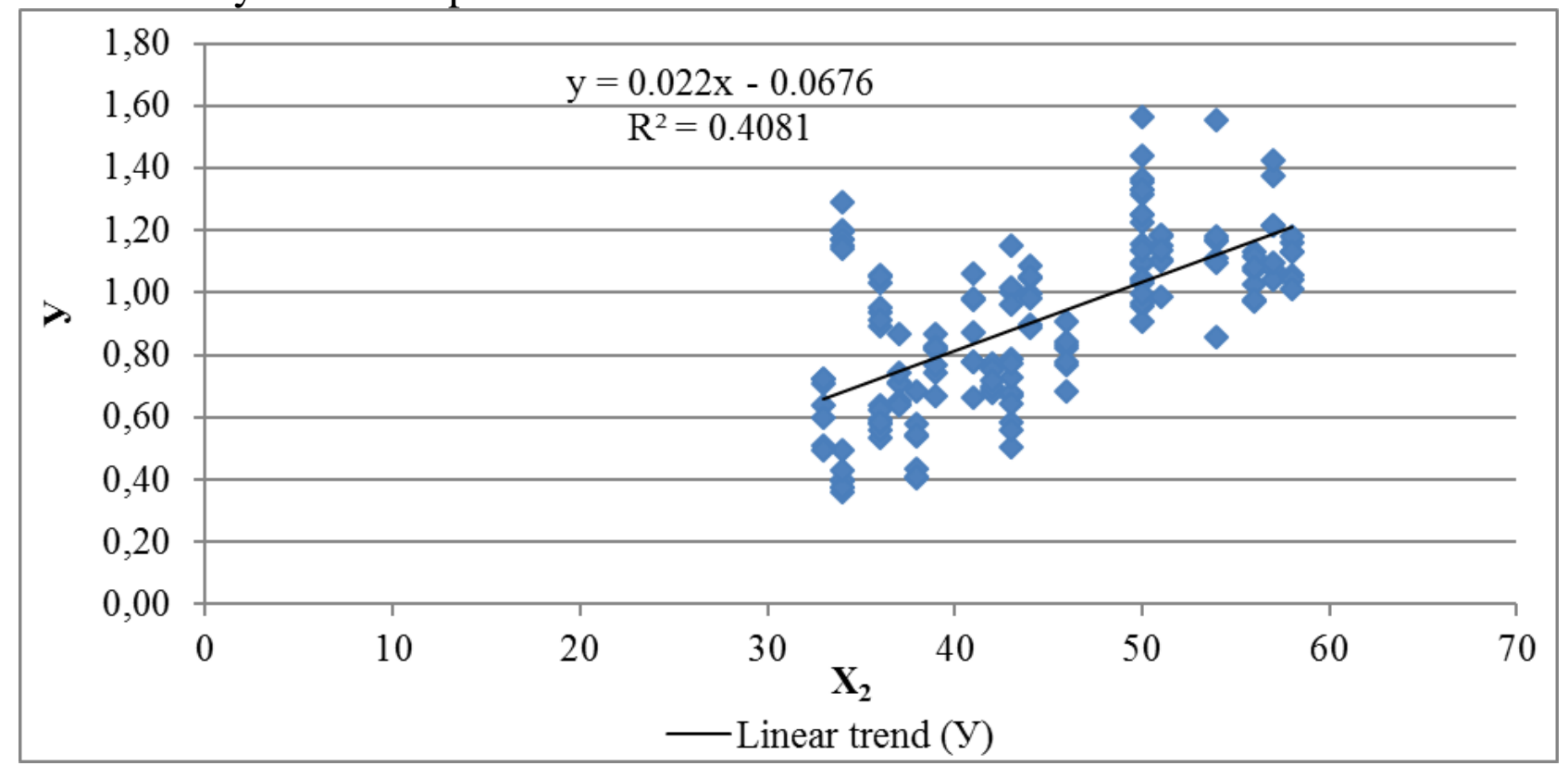

Fig. 3. Graph of dependence of the subindex of competitiveness by the grain yield (Y) on the ecological-agrochemical assessment of soil $\left(X_{2}\right.$, points) in agricultural enterprises of the districts of Chernihiv region, 2010-2016

Source: built by the authors on the basis of own research according to the data of the State Institution «Soils Protection Institute of Ukraine» and data of the form No. 50-s.g. 


\section{Agricultural and Resource Economics \\ www.are-journal.com}

At the second stage was studied the relationship between the ecologicalagrochemical assessment of soil and financial support, on the one hand, and the sustainable competitiveness of enterprises, on the other hand. Based on the results of correlation analysis, econometric models are constructed (Fig. 4-5). The developed double-factor econometric models of linear and non-linear (quadratic) types secured quantitative estimating of the combined impact of the parameters of soil fertility and financial support of production on the competitiveness of agricultural enterprises. The mentioned models can be considered as specific production functions with some modification of the factors, i.e. operating (production) expenses per 1 ha perform as a capital (financial support), whereas parameters of soil fertility serve as a land factor.

As it was expected, in Volyn region an increase of the ecological-agrochemical assessment of soil by 1 point and financial support by $1 \mathrm{thsd}$. USD/ha caused the subindex of competitiveness by the yield of winter wheat increased on average by 0.029 and 0.689 respectively. The model calculations demonstrate that in the variant of relatively low financial support of production (300 USD/ha), the increase of the ecological-agrochemical assessment of soil (from 25 to 45 points, i.e. 1.8 times) caused comparatively greater impact on the subindex of competitiveness by the yield (it increases 2.5 times - from 0.389 to 0.961 ) than in the variant of relatively higher financial support (900 USD/ha), where the subindex increased 1.7 times (from 0.802 to 1.374 ). In the variant of relatively low fertility ( 25 points), the three times increase of financial support (from 300 to $900 \mathrm{USD} / \mathrm{ha}$ ) caused a greater impact on the mentioned subindex (it increased 2.1 times) than in the variant of higher fertility (45 points). Both models are statistically significant (Table 5). However, some coefficients in the quadratic model are statistically unreliable. Thus, in the process of management it is recommended to give preference to the linear model, which is of the appropriate statistical quality.

Table 5

Parameters of econometric models of dependence of the subindex of competitiveness by the yield of winter wheat grain on the ecological-agrochemical assessment of soil and financial support for its production on the example of agricultural enterprises of the districts of Volyn region, 2010-2016 $(n=93)$

\begin{tabular}{|c|c|c|}
\hline \multirow{2}{*}{$\begin{array}{c}\text { Statistical } \\
\text { characteristics }\end{array}$} & \multicolumn{2}{|c|}{ Indicators and their meanings } \\
\hline & Linear model & Quadratic model \\
\hline $\begin{array}{l}\text { Coefficient of multiple } \\
\text { correlation }(R)\end{array}$ & $R=0.838$ (high correlation) & $R=0.864$ (high correlation) \\
\hline $\begin{array}{l}\text { Coefficient of multiple } \\
\text { determination }\left(R^{2}\right)\end{array}$ & $\begin{array}{l}R^{2}=0.703 \text { (statistically significant } \\
\text { because significance } F<0.05 \text { ) }\end{array}$ & $\begin{array}{l}R^{2}=0.746 \text { (statistically significant } \\
\text { because significance } F<0.05 \text { ) }\end{array}$ \\
\hline Fisher's F-criterion & $\begin{array}{l}F_{\text {fact }}=106.4 ; F_{\text {tabl }}=2.90-\text { at } 95 \% \\
\text { probability level; } F_{\text {fact }}>F_{\text {tabl }}\end{array}$ & $\begin{array}{l}F_{\text {fact }}=51.0 ; F_{\text {tabl }}=5.87-\text { at } 95 \% \\
\text { probability level; } F_{f a c t}>F_{t a b l}\end{array}$ \\
\hline Student's t-criterion & $\begin{array}{l}t_{f a c t}=26.8 ; t_{t a b l}=1.98-\text { at } 95 \% \\
\text { probability level; } t_{f a c t}>t_{\text {tabl }}\end{array}$ & $\begin{array}{l}t_{f a c t}=32.3 ; t_{\text {tabl }}=1.98-\text { at } 95 \% \\
\text { probability level; } t_{\text {fact }}>t_{\text {tabl }}\end{array}$ \\
\hline $\begin{array}{l}\text { Standard error of } \\
\text { estimation }\end{array}$ & 0.171 & 0.161 \\
\hline
\end{tabular}

Source: author's calculations. 


\section{Agricultural and Resource Economics}

www.are-journal.com

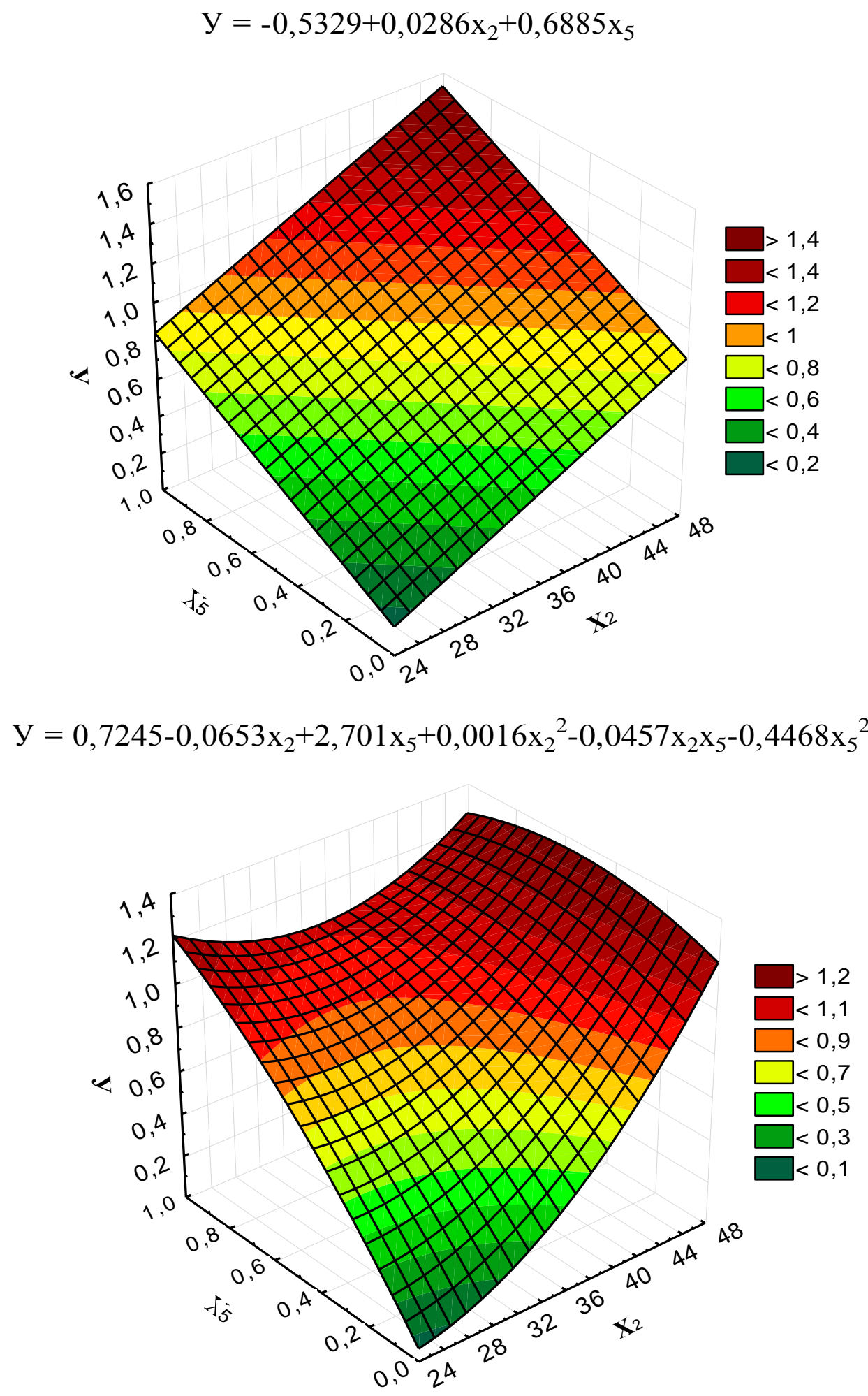

a)

b)

Fig. 4. Linear (a) and quadratic (b) models of the dependence of the subindex of competitiveness by the yield of winter wheat grain ( $Y$, coefficient) on the ecological-agrochemical assessment of soil ( $X_{2}$, points) and financial support for its production ( $X_{5}$, thsd. USD/ha of harvested area) on the example of agricultural enterprises of the districts of Volyn region, 2010-2016

Source: built by the author on the basis of his own research according to the data of the form No. 50-s.g. and data of the State Institution «Soils Protection Institute of Ukraine». 


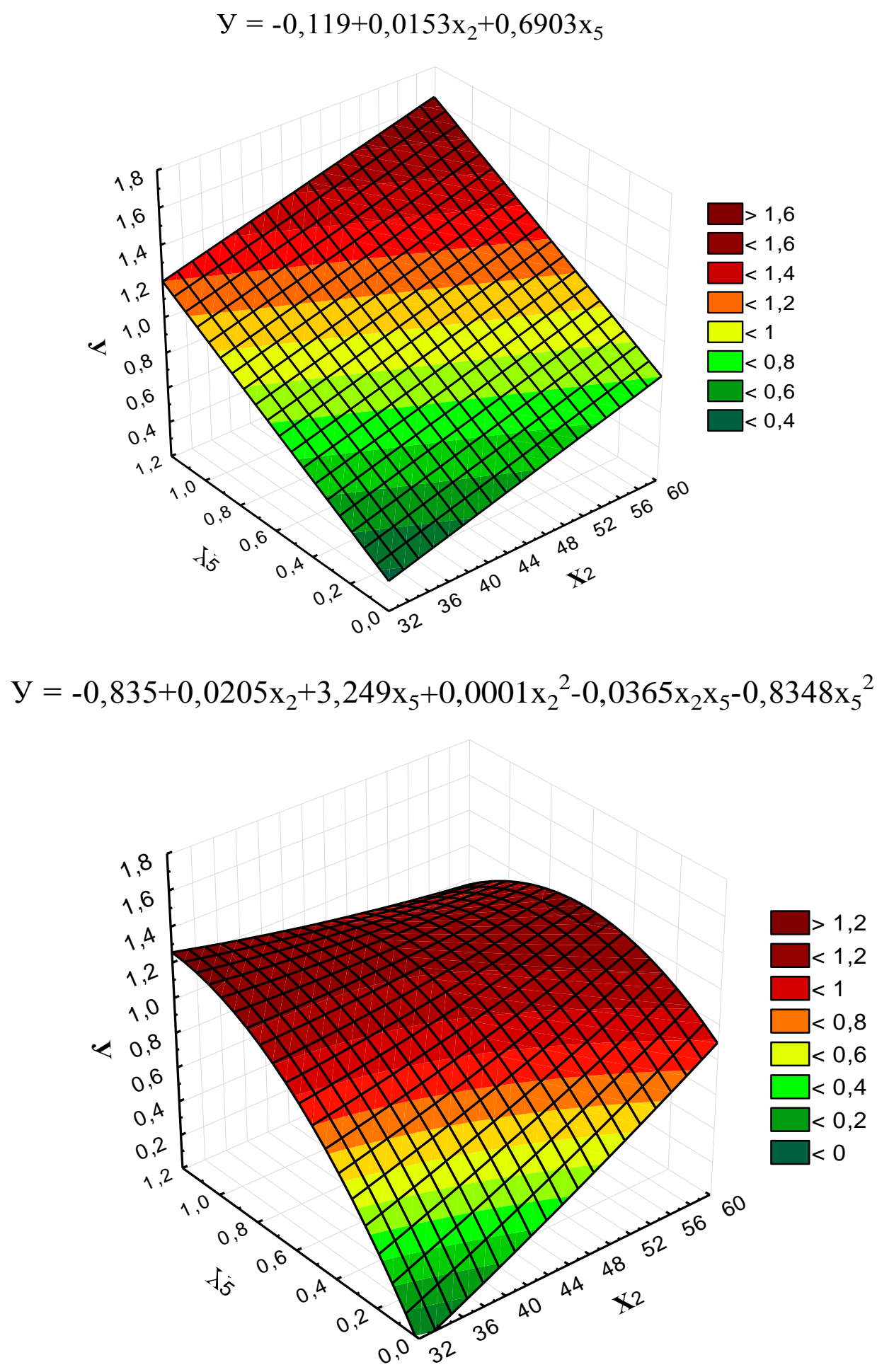

a)

b)

Fig. 5. Linear (a) and quadratic (b) models of the dependence of the subindex of competitiveness by the yield of grain $(Y$, coefficient) on the ecologicalagrochemical assessment of soil ( $X_{2}$, points) and financial support for its production $\left(X_{5}\right.$, thsd. USD/ha of harvested area) on the example of agricultural enterprises of the districts of Chernihiv region, 2010-2016

Source: built by the author on the basis of his own research according to the data of the form No. 50-s.g. and data of the State Institution «Soils Protection Institute of Ukraine».

The example of Chernihiv region demonstrates that the increase of the 
ecological-agrochemical assessment of soil by 1 point and financial support by 100USD/ha has secured the growth of the subindex of competitiveness by the yield of grain by 0.015 and 0.069 respectively. The coefficient of a multiple determination for a linear model confirms that variation of the dependent variable is by $57.7 \%$ caused by the variation of the included factors (Table 6).

Table 6

Parameters of econometric models of dependence of the subindex of competitiveness by the yield of grain on the ecological-agrochemical assessment of soil and financial support for its production on the example of agricultural enterprises of the districts of Chernihiv region, 2010-2016 $(n=88)$

\begin{tabular}{|c|c|c|}
\hline \multirow{2}{*}{$\begin{array}{c}\text { Statistical } \\
\text { characteristics }\end{array}$} & \multicolumn{2}{|c|}{ Indicators and their meanings } \\
\hline & Linear model & Quadratic model \\
\hline $\begin{array}{l}\text { Coefficient of multiple } \\
\text { correlation }(R)\end{array}$ & $R=0.760$ (high correlation) & $R=0.806$ (high correlation) \\
\hline $\begin{array}{l}\text { Coefficient of multiple } \\
\text { determination }\left(R^{2}\right)\end{array}$ & $\begin{array}{l}R^{2}=0.577 \text { (statistically significant } \\
\text { because significance } F<0.05 \text { ) }\end{array}$ & $\begin{array}{l}R^{2}=0.650 \text { (statistically significant } \\
\text { because significance } F<0.05 \text { ) }\end{array}$ \\
\hline Fisher's F-criterion & $\begin{array}{l}F_{f a c t}=58.0 ; F_{t a b l}=2.85-\text { at } 95 \% \\
\text { probability level; } F_{f a c t}>F_{t a b l}\end{array}$ & $\begin{array}{l}F_{f a c t}=30.5 ; F_{\text {tabl }}=5.82-\text { at } 95 \% \\
\text { probability level; } F_{f a c t}>F_{t a b l}\end{array}$ \\
\hline Student's t-criterion & $\begin{array}{l}t_{\text {fact }}=19.4 ; t_{\text {tabl }}=2.00-\text { at } 95 \% \\
\text { probability level; } t_{\text {fact }}>t_{\text {tabl }}\end{array}$ & $\begin{array}{l}t_{f a c t}=21.2 ; t_{\text {tabl }}=2.00-\text { at } 95 \% \\
\text { probability level; } t_{f a c t}>t_{t a b l}\end{array}$ \\
\hline $\begin{array}{l}\text { Standard error of } \\
\text { estimation }\end{array}$ & 0.182 & 0.169 \\
\hline
\end{tabular}

Source: author's calculations.

So, both models are statistically reliable. However, in the quadratic function, some regressors are statistically unreliable. Thus, to make forecast, it is better to use a linear function, whereas for other goals both of them can be used. It is determined that an increase of the ecological-agrochemical assessment of soil by one standard deviation (in case other factors stay unchanged) causes the subindex of competitiveness increases by 0.435 of its standard deviation, whereas the increase of the volume of expenses results in its growth by 0.481 of its standard deviation.

Conclusions. This paper presents empirical evidence for the impact of the soil fertility and financial support on the formation of sustainable competitiveness of enterprises. For the first time, one- and two-factor linear and quadratic econometric models were developed, which made it possible to carry out quantitative assessment of the impact of the ecological-agrochemical assessment of soils and the financial support per hectare on the formation of the subindex of competitiveness by the yield in various soil-climatic zones of Ukraine. The provision on the formation of the subindex of competitiveness by the yield under the conditions of the economic law of diminishing returns, was further developed.

The obtained results prove the hypothesis of a positive relationship between the ecological-agrochemical assessment of soils, financial support per hectare, and the sustainable competitiveness of subjects, however, the level of impact of soil fertility differs significantly in different soil-climatic conditions. It is shown that soil fertility and financial support can sometimes act as substitutes, for example, in a zone of 


\section{Agricultural and Resource Economics}

www.are-journal.com

insufficient moisture or low soil fertility. Increasing the financial support for agricultural production per hectare may be a strategy to increase productivity when soils are less fertile. At the same time, with a low financial support for production, it is almost impossible to achieve a zone of competitiveness even at high quality soil. The model calculations demonstrate that in the variant of relatively low financial support of production (300 USD/ha), the increase of the ecological-agrochemical assessment of soil (from 25 to 45 points, i.e. 1.8 times) caused comparatively greater impact on the subindex of competitiveness by the yield (it increases 2.5 times - from 0.389 to 0.961 ) than in the variant of relatively higher financial support (900 USD/ha), where the subindex increased 1.7 times (from 0.802 to 1.374). In the variant of relatively low fertility ( 25 points), the three times increase of financial support (from 300 to $900 \mathrm{USD} / \mathrm{ha}$ ) caused a greater impact on the mentioned subindex (it increased 2.1 times) than in the variant of higher fertility (45 points).

Hence, the example of Volyn and Chernihiv region is used to develop the graphic-analytical models of the determined dependence with the appropriate trend and parameters of the obtained econometric models, which provide sufficient arguments for a close direct dependence of the subindex of competitiveness by the yield on the soil fertility and financial support. The main results of the study can be used for (i) estimation and forecasting of the level of competitiveness depending on the ecological-agrochemical assessment of soils and the financial support per hectare; (ii) determining the effect of measures to improve the soil fertility on the competitiveness; (iii) determining the impact of soil degradation on competitiveness of agribusiness entities; (iv) identification of reserves to improve competitiveness. The research should be continued and focus on the substantiation of the motivational mechanism for improving soil quality, and also on forecasting the level of sustainable competitiveness depending on soil fertility and forecast financial support for agricultural production.

\section{References}

1. Kopittke, P. M., Menzies, N. W., Wang, P., McKenna, B. A. and Lombi, E. (2019), Soil and the intensification of agriculture for global food security. Environment International, vol. 132,

105078 . https://doi.org/10.1016/j.envint.2019.105078.

2. Pan, J., Shang, Y., Zhang, W. J., Chen, X. and Cui, Z. (2020), Improving soil quality for higher grain yields in Chinese wheat and maize production. Land Degradation \& Development, vol. 31, is. 9, pp. 1125-1137. https://doi.org/10.1002/ldr.3515.

3. Baliuk, S. A., Solovey, V. B., Zakharova, M. A., Kucher, A. V. and Truskavetskyi, S. R. (2015), Analysis of information support for the condition of soil resources in Ukraine. Agricultural Science and Practice, vol. 2, no. 2, pp. 77-84. https://doi.org/10.15407/agrisp2.02.077.

4. Bartolomei, R. Di., Salvati, L. and Perini, L. (2013), An integrated indicator system for the assessment of land quality and soil degradation in a Mediterranean rural area. International Journal of Ecological Economics and Statistics, vol. 31, 
no. 4, pp. 87-101.

5. Colantoni, A., Grigoriadis, E. Sateriano, A., Zambon, I. and Salvati L. (2016), If the sky falls we shall catch larks: rethinking land quality and desertification risk into a regional science framework. International Journal of Ecological Economics and Statistics, vol. 37, no. 3, pp. 64-75.

6. Huera-Lucero, T., Labrador-Moreno, J., Blanco-Salas, J. and RuizTéllez, T. (2020), A framework to incorporate biological soil quality indicators into assessing the sustainability of territories in the Ecuadorian Amazon. Sustainability, vol. 12 , is. 7 , 3007. https://doi.org/10.3390/su12073007.

7. Salvati, L., Bajocco, S., Sabbi, A. and Zitti, M. (2011), Agro-environmental indicators and land quality in the Mediterranean Basin: a preliminary analysis. International Journal of Ecological Economics and Statistics, vol. 21, no. 11, pp. 107-114.

8. Vashisht, B. B., Maharjan, B., Sharma, S. and Kaur, S. (2020), Soil quality and its potential indicators under different land use systems in the Shivaliks of Indian Punjab. Sustainability, vol. 12, is. 8, 3490. https://doi.org/10.3390/su12083490.

9. Abdul Rahman, N., Larbi, A., Opoku, A., Tetteh, F. M. and Hoeschle-Zeledon, I. (2019), Crop-livestock interaction effect on soil quality and maize yield in Northern Ghana. Agronomy Journal, vol. 111, is. 2, pp. 907-916. https://doi.org/10.2134/agronj2018.08.0523.

10. Fantappiè, M., Lorenzetti, R., De Meo, I. and Costantini, E. A. C. (2020), How to improve the adoption of soil conservation practices? Suggestions from farmers' perception in western Sicily. Journal of Rural Studies, vol. 73, pp. 186-202. https://doi.org/10.1016/j.jrurstud.2019.11.001.

11. Mgolozeli, S., Nciizah, A. D., Wakindiki, I. I. C. and Mudau, F. N. (2020), Innovative pro-smallholder farmers' permanent mulch for better soil quality and food security under conservation agriculture. Agronomy, vol. 10, is. 4, 605. https://doi.org/10.3390/agronomy10040605.

12. Oldfield, E. E., Bradford, M. A. and Wood, S. A. (2019), Global metaanalysis of the relationship between soil organic matter and crop yields. Soil, vol. 5, pp. 15-32. https://doi.org/10.5194/soil-5-15-2019.

13. Ansong Omari, R., Bellingrath-Kimura, S. D., Sarkodee Addo, E., Oikawa, Y. and Fujii Y. (2018), Exploring farmers' indigenous knowledge of soil quality and fertility management practices in selected farming communities of the Guinea Savannah Agro-Ecological Zone of Ghana. Sustainability, vol. 10, 1034. https://doi.org/10.3390/su10041034.

14. de Souza Mello Bicalho, A. M. and dos Guimarães Peixoto, R. T. (2016), Farmer and scientific knowledge of soil quality: a social ecological soil systems approach. Belgeo, vol. 4. https://doi.org/10.4000/belgeo.20069.

15. Kuria, A. W., Barrios, E., Pagella, T., Muthuri, C. W., Mukuralinda, A. and Sinclair, F. L. (2019), Farmers' knowledge of soil quality indicators along a land degradation gradient in Rwanda. Geoderma Regional, vol. 16. e00199. https://doi.org/10.1016/j.geodrs.2018.e00199. 
16. Dechezleprêtre, A. and Sato, M. (2017), The impacts of environmental regulations on competitiveness. Review of Environmental Economics and Policy, vol. 11, is. 2, pp. 183-206. https://doi.org/10.1093/reep/rex013.

17. Muhammad, N., Scrimgeour, F., Reddy, K. and Abidin, S. (2015), The relationship between environmental performance and financial performance in periods of growth and contraction: evidence from Australian publicly listed companies. Journal of Cleaner Production, vol.102, pp. 324-332. https://doi.org/10.1016/j.jclepro.2015.04.039.

18. Schaller, L., Targetti, S., Villanueva, A. J. and Zasada, I. et al. (2018), Agricultural landscapes, ecosystem services and regional competitiveness - assessing drivers and mechanisms in nine European case study areas. Land Use Policy, vol. 76, pp. 735-745. https://doi.org/10.1016/j.landusepol.2018.03.001.

19. Di Falco, S. and Zoupanidou, E. (2017), Soil fertility, crop biodiversity, and farmers' revenues: evidence from Italy. Ambio, vol. 46(2), pp. 162-172. https://doi.org/10.1007/s13280-016-0812-7.

20. Bielik, P. and Rajčániová, M. (2004), Competitiveness analysis of agricultural enterprises in Slovakia. Agricultural Economics - Czech, vol. 50, pp. 556-560. https://doi.org/10.17221/5248-AGRICECON.

21. Lapa, V. V., Shybut, L. Y. and Azarenok, T. N. (2017), On the results of the second round of cadastral valuation of agricultural land in Belarus. Pochvovedenie $i$ agrohimija, no. 2(59), pp. 7-13.

22. Issanchou, A. (2016), Soil resource, at the core of competitiveness and sustainability issues in agriculture: an economic approach. Working Papers SMART - LERECO 16-01, INRA UMR SMART-LERECO, available at: http://ageconsearch.umn.edu/bitstream/230002/2/wp16-01.pdf.

23. Issanchou, A. (2019), Gestion de la variation de la qualité des sols par les agriculteurs: enjeux pour la rentabilité et la durabilité des exploitations agricoles françaises, available at: https://tel.archives-ouvertes.fr/tel-01976630.

24. Issanchou, A., Daniel, K., Dupraz, P. and Ropars-Collet, C. (2015), Soil resource, at the core of competitiveness and sustainability issues in agriculture: an economic approach. 4th AIEAA Conference, available at: https://www.aieaa.org/sites/default/files/issanchou-

soil_resource\%402c_at_the_core_of_competitiveness_and_sustainability_issues166_a.pdf.

25. Issanchou, A., Daniel, K., Dupraz, P. and Ropars-Collet, C. (2019), Intertemporal soil management: revisiting the shape of the crop production function. Journal of Environmental Planning and Management, vol. 62, is. 11, pp. 1845-1863. https://doi.org/10.1080/09640568.2018.1515730.

26. Mesel-Veseliak, V. Ya. (2009), Alignment of the economic conditions of business on lands of different quality, Ekonomika APK, no. 3, pp. 97-102.

27. Koshkalda, I. V. (2013), Economic regulation of land relations in the agrarian sector: theory, methodology, practice, Abstract of Dr.S. dissertation, Economics and management of national economy, NSC «Institute of Agrarian 


\section{Agricultural and Resource Economics}

www.are-journal.com

Economics», Kyiv, Ukraine.

28. Hulvanskyi, I. M., Polishko, M. P., Khytruk, O. H., Zadorozhna, S. V. and Prudkun, S. V. (2017), Stan rodiuchosti gruntiv, okupnist dobryv urozhaiamy silskohospodarskykh kultur ta balansy humusu i pozhyvnykh rechovyn u zemlerobstvi Kirovohradskoi oblasti za 2016 rik [State of soil fertility, payback of fertilizers by crop yields, and balances of humus and nutrients in agriculture of Kirovograd region in 2016], Kropyvnytskyi, Ukraine, available at: http://www.iogu.gov.ua/publikaciji/zbirnyky.

29. Kucher, A. (2018), Sustainable competitiveness of agricultural enterprises. Sustainable development and competitiveness of regions. Vol. 1. Ed. prof. O. Stoichkova. Academic publishing house «Talent», Plovdiv, Bulgaria.

30. Kucher, A. (2019), Sustainable soil management in the formation of competitiveness of agricultural enterprises. Academic Publishing House «Talent», Plovdiv, Bulgaria. https://doi.org/10.13140/RG.2.2.19554.07366.

31. Kucher, A. V. (2019), Assessment and cluster analysis of sustainable competitiveness of agricultural enterprises. Herald of the Economic Sciences of Ukraine, no. 1, pp. 49-59.

32. Kucher, A. (2019), Assessment of the impact of land quality on competitiveness of enterprises. Agricultural and Resource Economics, vol. 5, no. 2, pp. 99-120, available at: http://are-journal.com.

33. Kucher, A. (2019), Effect of the balance of soil organic carbon on the formation of sustainable competitiveness of agricultural enterprises. Agricultural and Resource Economics, vol. 5, no. 4, pp. 111-136, available at: http://are-journal.com.

34. Brzozowska, A., Bubel, D., Kalinichenko, A. and Nekrasenko, L. (2017), Transformation of the agricultural financial system in the age of globalisation. Agricultural economics - Czech, vol. 63, pp. 548-558. https://doi.org/10.17221/155/2016-AGRICECON.

35. Davydenko, N. M., $\quad$ Skrypnyk, H. O., $\quad$ Titenko, Z. M., $\quad$ and Zhovnirenko, O. V. (2019). Modeling of the optimum level of financial provision of Ukrainian enterprises innovative activities. Global Journal of Environmental Science and Management, vol. 5(SI), https://doi.org/10.22034/GJESM.2019.05.SI.22.

pp. 197-205.

36. Kolotukha, S., Gvozdej, N. and Vinnytska, O. (2019), Improving the level of financial support for agricultural enterprises. Agricultural and Resource Economics, vol. 5, no. 3, pp. 95-110, available at: http://are-journal.com.

37. Oliynyk, O., Adamenko, V. and Oliynyk, L. (2015), The comparative analysis of financial system of Czech Republic, Poland and Ukraine. Acta Universitatis Agriculturae et Silviculturae Mendelianae Brunensis, vol.63, no. 6, pp. 2067-2076. https://doi.org/10.11118/actaun201563062067.

38. Oliynyk-Dunn, O., Adamenko, V. and Žufan, P. A. (2017), Comparative analysis of debt financing models in Czech and Ukrainian agriculture. Acta Universitatis Agriculturae et Silviculturae Mendelianae Brunensis, vol. 65, no. 5, pp. 1729-1739. https://doi.org/10.11118/actaun201765051729. 


\section{Agricultural and Resource Economics}

www.are-journal.com

39. Oliynyk-Dunn, O., Wasilewski, M., Kvasha, S. and Adamenko, V. (2019), Financial system development and financing patterns of firms: evidence from Ukraine. Journal of East-West Business, vol.26, is. 1, pp.1-16. https://doi.org/10.1080/10669868.2019.1630045.

40. Kucher, A. (2019), Zonal features of formation and reserves of increasing the sustainable competitiveness of agricultural enterprises. Agricultural and Resource Economics, vol. 5, no. 3, pp. 77-105, available at: http://are-journal.com.

41. Yatsuk, I. P. ed (2018), Scientific research on monitoring and survey of Ukrainian agricultural lands by the results of 10th round (2011-2015), State Institution «Soils Protection Institute of Ukraine», Kyiv, Ukraine.

How to cite this article? Як цитувати цю статтю?

Стиль-ДСТУ:

Kucher A. Soil fertility, financial support, and sustainable competitiveness: evidence from Ukraine. Agricultural and Resource Economics. 2020. Vol. 6. No. 2. Pp. 5-23. URL: http://are-journal.com.

Style - Harvard:

Kucher, A. (2020), Soil fertility, financial support, and sustainable competitiveness: evidence from Ukraine. Agricultural and Resource Economics, vol. 6, no. 2, pp. 5-23, available at: http://are-journal.com. 